First Peoples Child \& Family Review

An Interdisciplinary Journal Honouring the Voices, Perspectives, and Knowledges of

First Peoples through Research, Critical Analyses, Stories, Standpoints and Media

Reviews

\title{
Early Learning for Aboriginal Children: Past, Present and Future and an Exploration of the Aboriginal Head Start Urban and Northern Communities Program in Ontario
}

\section{Angela Mashford-Pringle}

Volume 7, Number 1, 2012

URI: https://id.erudit.org/iderudit/1068870ar

DOI: https://doi.org/10.7202/1068870ar

See table of contents

Publisher(s)

First Nations Child and Family Caring Society of Canada

ISSN

1708-489X (print)

2293-6610 (digital)

Explore this journal

Cite this article

Mashford-Pringle, A. (2012). Early Learning for Aboriginal Children: Past, Present and Future and an Exploration of the Aboriginal Head Start Urban and Northern Communities Program in Ontario. First Peoples Child \& Family

Review, 7(1), 127-140. https://doi.org/10.7202/1068870ar

\section{Article abstract}

This article provides some key findings from a case study of the Aboriginal Head Start Urban and Northern Communities (AHSUNC) Program in Ontario. Some of the key findings were improved self-reported health status, commitment to cultural and linguistic revitalization, reduced tobacco use, improved knowledge of healthy living practices among Aboriginal children and their families. The number of off-reserve Aboriginal children that can experience AHSUNC is limited by funding and availability of space and human resources. The participants in this study have shown improved knowledge, interaction with their children, and increased understanding of their biculturedness within Ontario. Therefore it is important to increase this funding and continue to conduct research with AHSUNC projects across Ontario to document and highlight their successes as a model for other provinces/territories and early childhood programs.
This document is protected by copyright law. Use of the services of Erudit (including reproduction) is subject to its terms and conditions, which can be viewed online.

https://apropos.erudit.org/en/users/policy-on-use/ 


\title{
First Peoples Child \& Family Review
}

An Interdisciplinary Journal Honoring the Voices, Perspectives and Knowledges of First Peoples through Research, Critical Analyses, Stories, Standpoints and Media Reviews

\section{Early Learning for Aboriginal Children: Past, Present and Future and an Exploration of the Aboriginal Head Start Urban and Northern Communities Program in Ontario}

\author{
Angela Mashford-Pringle \\ PhD Candidate (ABD), Dalla Lana School of Public Health, University of Toronto, Toronto, ON, Canada
}

\begin{abstract}
This article provides some key findings from a case study of the Aboriginal Head Start Urban and Northern Communities (AHSUNC) Program in Ontario. Some of the key findings were improved self-reported health status, commitment to cultural and linguistic revitalization, reduced tobacco use, improved knowledge of healthy living practices among Aboriginal children and their families. The number of off-reserve Aboriginal children that can experience AHSUNC is limited by funding and availability of space and human resources. The participants in this study have shown improved knowledge, interaction with their children, and increased understanding of their biculturedness within Ontario. Therefore it is important to increase this funding and continue to conduct research with AHSUNC projects across Ontario to document and highlight their successes as a model for other provinces/territories and early childhood programs.
\end{abstract}

Keywords: Aboriginal, First Nations, early childhood development, early childhood, Canada, Ontario, programs

\section{Introduction}

This article focuses on the Aboriginal Head Start Urban and Northern Communities Initiative (AHSUNC), which served Indigenous peoples from all three Aboriginal groups ${ }^{1}$, with the majority of the participants in this study identifying as either First Nations or Métis. There are significant issues that Aboriginal people face including lower educational attainment, levels of employment, health status, increased poverty, loss of culture and language. More than one-third of Aboriginal people in Canada do not have a high school diploma and just over half of off-reserve First Nations people report their health as being excellent or very good. These factors are the result of colonialism, poor policy and legislation, and ignoring Aboriginal voices concerning their experiences, needs and desires. In order to reduce these negative factors,

Corresponding author:

Angela Mashford-Pringle

angela.mashford.pringle@utoronto.ca Aboriginal parents and Elders met with the federal government in 1993 to create a program that would give at-risk Aboriginal children a positive and culturally relevant head start before they begin elementary school.

1 In the current literature, the terms 'Indigenous' and 'Aboriginal' are often used interchangeably to describe all Indigenous groups in Canada, who were the original inhabitants in this country (Borrows, 1994; Posluns, 2007; Smith, 1999). Aboriginal people in Canada are comprised of three main groups: First Nations, Métis and Inuit peoples. The term 'Aboriginal' is used as it is the terminology used in the Constitution Act of 1982, the Charter of Rights and Freedoms, and by many federal government departments (Borrows, 1994; Posluns, 2007). 


\section{The Road to Developing the Aboriginal Head Start Urban and Northern Communities Program}

By 1763, the relationship between Aboriginal people and Europeans changed. After the Royal Proclamation expressly acknowledged Aboriginal people as allies and sovereign nations, the creation of Canada through British North America Act of 1867 made Aboriginal people wards of the state. Further colonialism and oppression occurred with the introduction of the Indian Act in 1876 (Miller, 1991). This oppressive legislation reflected and sought to implement the assimilation policy of the time.

Residential schools were opened in the 1880s and ran until 1996 (Stonechild, 2006). Generations of First Nations children were subjected to the rudimentary learning institutions where they experienced physical, sexual, emotional and verbal abuse (Aboriginal Healing Foundation, 2008; Stonechild, 2006). These schools were designed to eradicate First Nations languages and cultures by indoctrinating First Nations children in western worldview and teaching European languages (Battiste, 1986; Stonechild, 2006). Many First Nations parents and Elders recommended that Aboriginal children attend these schools to acquire a western education (Wotherspoon, 2004). Western education was prophesized to help Aboriginal people learn about the dominant culture and their economy, which would lead to new ways to provide food, clothing, shelter and governance for Aboriginal people (Stonechild, 2006). Many Elders and Aboriginal leaders have argued that education would be the new buffalo for Aboriginal people (Stonechild, 2006). However, many Indigenous scholars (Alfred, 2009; Ball, 2004; Battiste, 2000; Turner, 2006) argue that there is a need for culturally appropriate education that will assist Aboriginal people with working toward self-determination and self-governance by creating Turner's 'word warriors'. It is extremely important to educate young Aboriginal people in the western education system so that they can learn how it works, provide insight into the system, and begin to advocate for Aboriginal people within it.

The Canadian government has taken very small steps to improving the lives of Aboriginal people in Canada after centuries of colonization, assimilation tactics, and neglect. By the 1990's, the federal government had announced Aboriginal Early Childhood Development programs, intended to improve the lives of urban Aboriginal children (Greenwood, 2001; Palmantier, 2005). In 1994, Health Minister Dianne Marleau announced the Aboriginal Head Start Initiative (Palmantier, 2005). The Aboriginal Head Start Urban and Northern Communities Initiative provides community-based and community driven programming with a specific focus on culture and language, health, education, nutrition, social support, and parental involvement for Aboriginal children between the ages of 3 and 5 years old.

Many scholars (Barton, Thommasen, Tallio, Zhang, \& Michalos, 2005; Benoit, Carroll, \& Chaudhry, 2003; Cox, 2002; Greenwood, 2001; Newbold, 1998; Palmantier, 2005) have studied Aboriginal early childhood development and found there is a great need for such services, but there needs to be great improvements. Aboriginal Head Start is a building block for early childhood learning and development. Moving forward, federal government policies and programs could build on this well-received program and continue by working with Aboriginal peoples to ensure culturally relevant education for Aboriginal children and youth beyond preschool years. Culturally relevant programming can also help to improve health and health status by using a holistic and upstream approach that incorporates the social determinants of health (Health Canada, 1998). 
The social determinants of health were developed based on the Lalonde Report (1974), which suggested that health was more than the absence of disease and other factors influence an individual's health. Health Canada (1998) adopted the population health approach, which had twelve key social determinants of health, which are in Table 1, and can significantly impact an individual's life. Therefore, if there is an increase in educational attainment, it is likely that employability will be increased, which would then change the physical and social conditions a person experiences that can be affected by a number of different factors, not just education. If these change, then health status, or at least self-reported health, will likely improve (Tjepkema, 2002). Twenty-nine families participated in this research from the Waabinong Head Start in Sault Ste. Marie, Ontario. The results show a positive trend toward improved health, education and social support. Twenty-six percent of parents and caregivers responded that their general and mental health increased over the three months after being a part of the AHSUNC community, but there was a decrease in the parents/caregivers ratings of the child's health ( $23 \%$ declined). Ten percent of parents and caregivers returned to school, and 33\% of parents and caregivers changed their employment status in the period between the two surveys.

Table 1 Health Canada's Social Determinants of Health

Key Social Determinants of Health

\begin{tabular}{|l|l|}
\hline Income and Social Status & Social Support Networks \\
\hline Education and Literacy & Employment/Working Conditions \\
\hline Social Environments & Physical Environments \\
\hline Personal Health Practices \& Coping Skills & Healthy Child Development \\
\hline Biology and Genetic Endowment & Health Services \\
\hline Gender & Culture \\
\hline
\end{tabular}

Many changes have occurred in Aboriginal education in Canada over the past two hundred years. Communities have been dispersed, moved, relocated, and subject to policies and legislation which sought to assimilate Aboriginal peoples into mainstream society. From residential schools, which forced Aboriginal children to attend and learn a foreign language and culture, to provincial curriculum being mandated for on reserve schools, Aboriginal people have persevered to ensure that their traditional ways of teaching, learning, and knowledge transfer continue to occur, while policies and legislation have tried to prevent this.

In 1969, the Department of Indian Affairs released the 'White Paper'. The 'White Paper' or the Statement of the Government of Canada on Indian Policy, was introduced by Jean Chretien in June 1969. The paper outlined reforms that would abolish the Indian Act, which would enfranchise status First Nations people, abolish the reserves, and make First Nations people equal to all other Canadians (Weaver, 1981). The Red Paper,by Harold Cardinal and the National Indian 


\section{Early learning for Aboriginal children}

Brotherhood stated that the government's policy was unacceptable and would be detrimental to the existing rights and treaties that First Nations had signed. In 1972, the National Indian Brotherhood wrote the "Indian Control of Indian Education" paper also known as the 'Red Paper' (Barman, Hebert, \& McCaskill, 1986). While the federal government wanted to take full control of Indian education the National Indian Brotherhood, now the Assembly of First Nations, argued that parental responsibility and local control of education was necessary (National Indian Brotherhood, 1972). The Trudeau government agreed in principle to the 'Red Paper' and agreed to transfer control to Aboriginal people (Barman et al., 1986). The Department of Indian Affairs did not believe they could implement such a policy and the federal government has continued to find legal ways around allowing Aboriginal communities (both on and off reserve) to take control of education (Barman et al., 1986; Longboat, 1986).

By the early 1980s, regardless of poor funding from the federal government, more than 75 percent of Indian bands had taken control of their education either partially or fully. By taking control, Aboriginal people could develop and implement an Aboriginal specific curriculum, as well as determine where funds would be spent (Barman et al., 1986). Re are a number of barriers to on reserve education including funding, human resources, and facilities. By 1985 when the Indian Act was revised to restore status to thousands of First Nations people who previously lost it through marriage or other assimilatory provisions of the Indian Act, there were discussions by the federal government to create early learning and child care initiatives (Greenwood, 2001; Palmantier, 2005).

By the early 1990s, there was a great deal of activity surrounding early childhood development and child care. Politically, Aboriginal people had come to be a focus of various federal government programs, services, and reports. The provincial government in Ontario was still taking a standoff approach to Aboriginal people, even though greater numbers of Aboriginal people were migrating to urban centres like Toronto.

The Canadian government hosted the 1990 World Summit for Children and by 1991, the Royal Commission on Aboriginal Peoples had begun its investigation into the social issues surrounding Aboriginal people in Canada (Cox, 2002). By 1994, a discussion paper on Aboriginal childcare was released to the public and by the end of the year Minister Axworthy's Social Security Discussion Paper reaffirmed the federal government's commitment to First Nations and Inuit communities (Bennett, Blackstock, \& De La Ronde, 2005; Cox, 2002). As part of the federal government's commitment, they announced the Aboriginal Head Start Urban and Northern Communities Initiative (AHSUNC) and the First Nations and Inuit Child Care Initiative (FNICCI) to provide Aboriginal early childhood development that was directed and controlled by Aboriginal people in a holistic way (Ball \& Elliot, 2005; Greenwood, 2001; Health Canada, 2000; Palmantier, 2005).

\section{The Program}

AHSUNC is an off-reserve early learning program developed by and for Aboriginal children between 3 and 5 years old and their families. The program is provided in urban and northern communities across Canada on a four day per week cycle between September and June and is free to families as half day session similar to the local kindergarten program (Public Health Agency of Canada, 2002). There is no standard curriculum across the country, but each project uses a school readiness curriculum, such as high scope, infused with Aboriginal content, which includes culture and language components from the local Aboriginal communities. The high scope curriculum has been built around developmental milestones and provides teaching 
First Peoples Child \& Family Review, Volume 7, Number 1, 2012

practices that assist young children with learning language, literacy and communication; social and emotional development; physical development, health, and well-being; and arts and sciences (HighScope Curriculum, 2012). ASHUNC is one piece of the broader education and health promotion puzzle; it needs to provide young Aboriginal children with a sense of identity, heritage and bi-culturedness that will reduce the gaps in health and education that so many Aboriginal people experience in Canada.

For many Indigenous Peoples, they must navigate two cultures; Euro-centric and Indigenous. Navigating between the two cultures has been labelled "bi-cultured" by Brown and Smirles (2003). Indigenous Peoples, regardless of where they live, now live in a modern world where the dominant society or world order has been mostly derived from historical imperial political structures that brought colonization violence and capitalism upon Indigenous cultures. An ethnocentric and Eurocentric culture in the Americas, particularly in North America, has dominated Indigenous Peoples social orders. Indigenous Peoples today are restoring their practices within their cultures but are still working and living within the Eurocentric culture. This may lead to internal conflict in terms of spirituality, social relations, and economic patterns that may lead to negative behaviours that contribute to mental health and health problems.

Children who learn their own culture and that of the majority culture become bi-cultured as they grow to understand the traditions, celebrations, religion(s), rights, and beliefs for both the mainstream and their family culture. Brown and Smirles (2003) argue that urban Aboriginal children and youth learn about their "bi-culturedness" from their parents and extended family as they provide the children with knowledge about how to negotiate the oppressive society outside their front door. Other scholars (Friedel, 1999; Ball, 2004) further argue that dedicated culturallyspecific programs are effective if families become involved in the education used by EuroCanadians, otherwise the program goals and achievements will be lost or have little or no effect as the children do not see themselves reflected in the curriculum. It is necessary for Aboriginal in Canada to be cognizant of the political and legal issues that separate their self-perceived identity from the "acknowledged" identity (legally defined by the federal government), but to decolonize and connect with traditional teachings like the Seven Grandfather teachings that many Ontario First Nations believe in, it is necessary to have an identity that blends their Aboriginal and nonAboriginal identities together in a bi-cultured way (Mishibinijima, 2004).

The first six AHSUNC projects in Ontario recruited children who were living in low-income or single parent families and those who were at risk for abuse, neglect or in child protection. There are six core components to AHSUNC: education and school readiness, health promotion, nutrition, parental/family involvement, social support, and culture and language. Elders, Aboriginal community members, and parents were brought together to review the American Head Start program and used components of that program for the inception of the Canadian Aboriginal head Start program. The core components work holistically to improve Aboriginal children's lives from different perspectives, with the values and beliefs of the program providing guidance as to how to implement the core components. Some of the values and beliefs are: that children "have a right" to be proud of being Aboriginal, learn an Aboriginal language and worldview, receive guidance in a culturally appropriate manner, have the right to acquire knowledge in an experiential manner, and be loved by their family and community while living a healthy lifestyle.

All AHSUNC projects in Ontario are licensed as daycare facilities under the Ontario Day Nurseries Act (DNA), which stipulates that all teaching staff must have an Early Childhood Educator (ECE) diploma and pass a criminal reference check before working with children. There 
are currently 14 AHSUNC projects in Ontario funded by the Public Health Agency of Canada's Ontario Region office. The projects are located in Sioux Lookout, Kenora, Fort Frances, Thunder Bay, Sault Ste Marie, Moosonee, Hamilton, Fort Erie, one Inuit project and one First Nations and Métis project in Ottawa, and four locations representing the four directions of the Medicine Wheel in Toronto shown in Figure 1. In 2005, there were approximately 560 children enrolled in these Ontario projects with regional budget of $\$ 5,548,000$ for all sites. There is some variability in the levels of funding of the Ontario AHSUNC projects, but each project receives money for personnel, transportation, materials including meals, and evaluation. The project funding is reviewed and renewed based on the Treasury Board Secretariat policies and procedures with another renewal cycle occurring after April 1, 2013. Future programming is dependent on the level of funding and sustainability of the funding (Leitch, 2008).

Figure 1: Map of Aboriginal Head Start Urban and Northern Communities Projects in Ontario

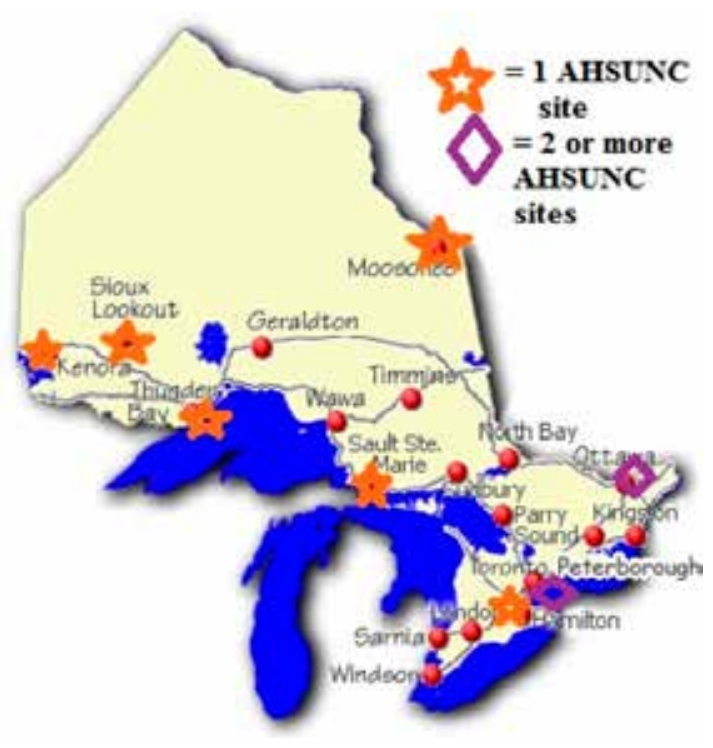

The Aboriginal population is the fastest growing population in Canada at 1.7 times faster than the non-Aboriginal rate (Cox, 2002; Hanselmann, 2001; Mendelson, 2006). The statistics also show that more than 62 percent of the Aboriginal identity population resides in off reserve areas like cities and rural towns (Mendelson, 2006). The Aboriginal population is younger than the overall Canadian population. According to Statistics Canada (2006), the there is a total of 147,820 self-identified Aboriginal people in Ontario with 17,400 of those being children between 0 and 4 years of age in off reserve communities (Figure 2). As mentioned early, 560 Aboriginal children between 3 and 5 years old receive AHSUNC programming, which is approximately three percent of the off reserve self-identified Aboriginal children in Ontario. However, Tjepkema (2002) states that an overwhelming number of Aboriginal people suffer from low education, under and unemployment, and health issues, which means that the program is in far greater need than it is funded to provide. AHSUNC was created to give Aboriginal children a "head start" in education, but the program offers health promotion activities and practices that may also improve the health status of these children and their families.

Many scholars have noted that social problems like alcoholism, family violence and chronic unemployment all stem from the lack of control of the education system for Aboriginal people (Frideres \& Gadacz, 2001; Mackay \& Myles, 1995); therefore it is necessary to establish research that proves that Aboriginal controlled education works the best for Aboriginal people and that many social problems can be addressed if Aboriginal people feel a sense of pride in their identity, even as they are faced with belonging in two different cultural worlds. A sense of pride is clearly a key component of AHSUNC, which leads to improved self-esteem. Self-esteem is intrinsically linked to the way a person is identified, as Dawson (1988) argues that if children are proud to be identified as "Indian", than they will have higher self-esteem than the Aboriginal children who do not want to identify as "Indian" or "Aboriginal". Therefore it is important to 
Fig 2: Ontario's Age Pyramid - All ages

\section{Ontario's Age Pyramid (2006)}

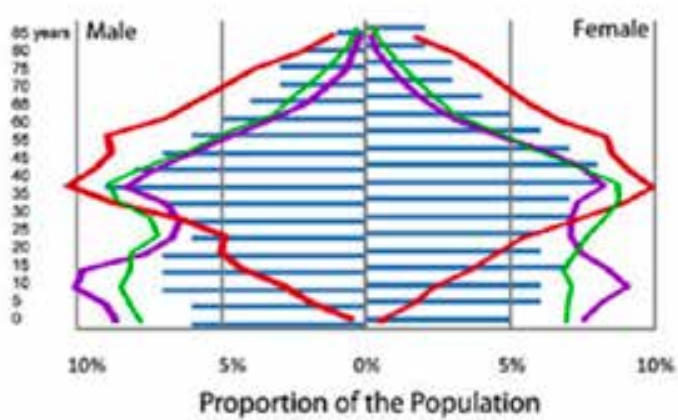

Source: Ministry of Citizenship and Immigration (n.d). In presentation "Aging and the Not-for-Profit Sector: Ready or Not? http://www.citizenship.gov.on.ca/english/pp/ next10/presentations/aging.shtml. note that Aboriginal people in Canada have been defined by a paternalistic federal bureaucracy, which has excluded many selfidentified Aboriginal people through policies and legislation. The mere idea of defining and labelling are colonizing and paternalistic, which can also contribute to poor health status as it affects self-esteem, and can in turn start the cycle of believing/being hopeless within an industrialized society. Corenblum (1996) and Mishibinijima (2004) argue that being defined as a specific ethnic group can be detrimental if the ethnic group in question does not have preferential status in the society.

Many scholars (Greenwood, 2001; Newbold, 1998; Palmantier, 2005; Stonechild, 2006; Turner, 2006) argue that improving Aboriginal educational attainment will have an impact on employability, health status, social support, and self-governance. AHSUNC is primarily aimed at the children in attendance, but parents and caregivers also benefit from the informal education, social support, volunteer experiences, and health promotion information they receive at workshops, in parent/teacher interviews, cultural events, and through their children. In addition, some parents/caregivers are involved in board governance, which teaches them about policy development and how governance works.

Parents and families are the first teachers that children have. May and Aikman (2003) and Friedel (1999) argue that parents and families play a vital role in advocacy at school and ensuring that the child learns about their cultural identity and language early. Having parents/caregivers who teach and pass on culture and language in the home will increase the likelihood that children will continue to learn about their culture beyond what their caregivers teach and will be more receptive to learning more. AHSUNC projects across Canada provide one avenue for children and their families to learn more about their traditions in hopes that Aboriginal cultures and languages can continue to be revitalized and transmitted to generations to come. It is very important to create policies in Canada that support this revitalization as a "protective" factor occurs when there is policy or legislation around an "endangered" aspect of life.

\section{Methodology}

In January 2007, I approached the Ontario Aboriginal Head Start Association (OAHSA) to determine if there was research around health and education that I could conduct with them. Waabinong Head Start in Sault Ste. Marie and Fort Erie Head Start agreed to participate, but due to low responses from Fort Erie, they were excluded from the study. The Program Coordinator for Waabinong worked with the Parent Council to create and review questionnaires and assist with recruitment. The questionnaire produced for September asks participants demographic data as well as health, education, social support, culture and language questions. The second questionnaire for December is similar to the first questionnaire without the demographic data being collected and some additional questions regarding changes in education, employment, 


\section{Early learning for Aboriginal children}

culture and language. These questionnaires were developed to meet the needs of this study and to provide information to the projects about their program and its' effectiveness. The questionnaires had both quantitative and qualitative questions to improve reliability and validity. The Parent Council determined that every parent/caregiver with a child enrolled in the 2007/08 school year would be asked to participate in the survey. Ethics approval was sought and awarded in July 2007 by the University of Toronto Research Ethics Board.

Data analysis was conducted for all quantitative questions in SPSS and qualitative openended responses were collated in Word 2007. Analysis was done on the initial questionnaire, then on the second questionnaire, then as a comparison of the two answered questionnaires. Looking at the mean and correlation percentages, I checked for statistical significance with Chi square and through t-tests. By looking at frequency tables, cross-tabulations, and the means, trends were revealed for (a) the September questionnaires, (b) the December questionnaires, and (c) the comparison of the two questionnaires. There were a total of 29 respondents to both questionnaires (September and follow-up in December 2007) from Waabinong Head Start. There were 44 responses from September, but only 29 families remained in December of the possible 44 families. The questionnaires were numbered by a family number to ensure that identities were not revealed.

\section{Findings and Discussion:}

\section{Demographics about Waabinong Head Start:}

The demographic data for Waabinong Head Start was:

- $90 \%$ of primary caregivers identified as the mother of the child

- $90 \%$ of second caregivers identified as fathers or step-parents

- 23 families were single parents or caregivers

- 6 families had two caregivers or parents

- average level of education was high school completion

\section{Skill Development:}

In the first three months of attending the program, it is apparent that Aboriginal children show an improvement in their school readiness and early learning skills as well as improved health routines (i.e. teeth brushing and regular doctor and dental visits). Parents and caregivers provided qualitative responses about their child's new skills and knowledge. Sixty-five percent of children are potty-trained in the first three months of attendance at AHSUNC and more than $90 \%$ of children had shown improvements in language, reading and math skills. Parents and caregivers reported improved health routines with their children as well (i.e. teeth brushing, regular doctor visits, and dental visits).

\section{Health and Well-Being:}

Parents and caregivers also show improvements in educational attainment, employment, social supports, self-perceived health and mental health status, and health behaviours (i.e. reduced tobacco consumption, increased dental and doctor visits, improved knowledge of illegal drug 
effects, etc.). The health and education of the parents and caregivers was also improved as they showed a $26 \%$ increase in health and mental health reports with $10 \%$ who returned to school. Since one third of all caregivers/parents changed their employment status between September and December, it is likely that some of these people did perceive their health as improved because they had meaningful employment that they did not have when completing the first questionnaire. As AHSUNC parents and caregivers began to have a positive sense of identity in being Aboriginal, it is likely that it improved their self-esteem, which in turn could have led to employment and educational opportunities. These improvements are significant and show that a positive environment and social support can improve health and education as suggested in the Ball and Elliot (2005) study, which showed that increases in social support improved the health and educational readiness of children and their families. While these improvements cannot be fully attributed to AHSUNC, it is likely that AHSUNC played an important role in the changes made to both the children and their families through a holistic approach.

Waabinong families also showed an increase in knowledge regarding health promotion and healthy living, as well as how to access "western" health professionals and traditional healers after being in the program for three months. With an increased knowledge and use of health professionals, it is likely that longitudinally these families will have improved self-reported health status compared to other Aboriginal families who do not attend AHSUNC. In partnership, Aboriginal organizations and the federal government should develop health promotion policies ensure equitable access for all Aboriginal people, whether they live on or off reserve, and build upon the successes of the health promotion programs offered by the Public Health Agency of Canada and First Nations and Inuit Health Branch of Health Canada.

A surprising finding in this study was change in tobacco consumption. Ten percent of primary caregivers quit smoking between September and December and almost $20 \%$ decreased the frequency of smoking and more than $22 \%$ changed where they smoked (outdoors versus in the home or car). With these caregiver changes, it is not surprising that $19 \%$ of children were no longer in the presence of cigarette smoke in the home or car at the end of the study. These changes in smoking behaviour could be attributed to the health promotional materials provided to the children and their families at AHSUNC. This finding is positive, but research has shown that some smokers quit smoking only to begin again and must repeat the behaviour change stages up to seven times before they quit permanently (Physicians for a Smoke-Free Canada, 2008). If $10 \%$ of primary caregivers quit smoking after their children had been in AHSUNC for just three months, it would be beneficial to create linkages between various health promotion issues and social programs like AHSUNC. These linkages and partnerships may increase the knowledge of participants and ultimately be the impetus to positive health behaviour changes over time.

The Federal Tobacco Act provides the basic legislation for tobacco consumption and sales, each province has also enacted legislation regarding tobacco consumption and sales. For urban Aboriginal people, it may be beneficial to work from a traditional knowledge perspective; therefore using the traditional knowledge that tobacco is used to request knowledge from others, used in smudging ceremonies, and is considered a medicine by some Aboriginal cultures. Aboriginal organizations could look at policy development around subjects like commercial tobacco consumption and help Aboriginal organizations, on and off reserve, to transmit traditional knowledge about tobacco use to Aboriginal people. Since the study's completion in 2008, there has been considerable research and policy development in the area of Aboriginal tobacco control including the re-development of a federally funded cessation and education program. 


\section{Early learning for Aboriginal children}

\section{Incorporating Culture, Language and Knowledge:}

In qualitative responses, caregivers and parents consistently voiced that they want their children to learn their Aboriginal culture and language. More than $90 \%$ of families wanted to learn and use the culture and language that were taught in their homes. This finding is supported by many scholars (Adelson, 2005; Bramley, Hebert, Jackson, \& Chassin, 2004; Bramley, Hebert, Tuzzio, \& Chassin, 2005; Cheshire, 2001; Greenwood \& Shawana, 2000) who also argue that positive selfidentity in being Aboriginal and being able to practice and use Aboriginal culture and language will assist in revitalization and transmission of culture and language into future generations. Lertzman (2002) found that Aboriginal peoples, their land and teachings can lead them toward transformation that further develops their traditional knowledge and worldview and this can assist young people in becoming a 'whole human being'.

To ensure that Aboriginal cultures and languages are revitalized and transmitted to future generations, Bramley et al. (2004) argue that language nests are essential. In New Zealand, the Maori have developed a language learning system that immerses young children in the Maori language in the preschool programs. In Canada, there is no education policy that covers all Aboriginal peoples, therefore it would be essential for provinces and territories and the federal government to work with Aboriginal people (as per the RCAP recommendations) to implement language nests or something similar, which could help with revitalization and transmission of cultures and languages in a positive way. Education policies, much like Aboriginal research guidelines (OCAP), should come from the people that it will be for; therefore it would be prudent to reflect on the current educational situation of Aboriginal peoples and how this can be improved (Stonechild, 2006).

\section{Education and Employment of Parents and Caregivers:}

Some of the other interesting findings include: one quarter of families were already visiting a Traditional Healer and/or smudging at home, however $88 \%$ had begun to incorporate culture and language from AHSUNC into their homes; there was a $12 \%$ increase in visits with an Aboriginal Social Support Worker; $10 \%$ of caregivers returned to school with another $12 \%$ intending to return to school in the future; $22 \%$ of stay-at-home primary caregivers returned to the workforce and $11 \%$ of second caregivers moved from part-time to full-time employment; approximately $26 \%$ of caregivers rated their health and mental health improved, but $23 \%$ rated their child's general health decreased. As the parents and caregivers understand health issues more, they may reflect on their child's health differently which leads to a decreased perception of health. There was also a $20 \%$ decrease in the frequency of smoking with $22 \%$ changing where they smoked; and finally there was increase in the use of other social programs like the Ontario Early Years Centres. This shows that AHSUNC has had a positive effect on the children and families by helping to increase health, education, employment, and social support networks. Of the 29 families that completed both the September and December questionnaires, there was a trend toward healthier lifestyle choices, improved education of the children, upward mobility in employment, increases in self-reported general and mental health of caregivers, and decreases in habits like smoking and alcohol use.

Waabinong Head Start clearly offers more than just school readiness for 3 to 5 year old First Nations and Métis children in the Sault Ste Marie area. The results of the study show that parents and caregivers also benefit from their children attending AHSUNC. Waabinong Head Start is an established project, which began in 1994, and therefore has many ties in the urban community as 
First Peoples Child \& Family Review, Volume 7, Number 1, 2012

well as in Garden River First Nation. It is clear that funding such social programs for Aboriginal people with Aboriginal people involved in the planning, implementation, and continued functioning is important to the overall success of the program. First Nations and Métis families in Sault Ste Marie, Ontario have created a very supportive community that also assists other First Nations and Métis families in the area with raising their children and learning traditional knowledge, culture and language.

The impacts of AHSUNC go beyond the six core components of the program and are defined, captured, and reported on in this study. In the first three months of attending the program, it is apparent that Aboriginal children show an improvement in their school readiness and early learning skills as well as improved health routines and nutrition. Parents and caregivers also show improvements in educational attainment, employment; social supports, self-reported health and mental health status, and health behaviours (i.e. reduced tobacco consumptions, increased dental and doctor visits, etc.).

\section{Conclusion}

Aboriginal education for Aboriginal people by Aboriginal people creates healthier communities; similarly, Aboriginal policy development for Aboriginal people by Aboriginal people is more likely to create sensitive, revitalizing, meaningful and healing policy that is of benefit to Aboriginal people. Aboriginal voices have often been excluded from policy tables, but it is necessary to hear from the source how to decolonize and begin the healing journey that so many Aboriginal families have or are starting to undertake. Future policies and policy research needs to hear Aboriginal voices to help with decolonization, which will ultimately lead to individual and community healing. AHSUNC is one piece of the decolonization puzzle, but many other policies for early childhood learning need to be developed with Aboriginal people at the helm.

Using the Sault Ste. Marie site as a case study, this article has provided an overview of some positive changes experienced by Aboriginal children and families that attend AHSUNC in Ontario. The federal government needs to increase the amount of funding available for this program to allow more Aboriginal peoples to access this programming for their families. The provincial government must continue to assist AHSUNC in working within the Day Nurseries Act to revitalize and reclaim Aboriginal cultures and languages across Ontario. Therefore more research, networking, and funding are required to help Ontario's Aboriginal communities to further improve their health and education status.

\section{References}

Aboriginal Healing Foundation. (2008). From Truth to Reconciliation: Transforming the Legacy of Residential Schools. Ottawa, Ontario: Aboriginal Healing Foundation.

Adelson, N. (2005). The embodiment of inequity - Health disparities in Aboriginal Canada. Canadian Journal of Public Health-Revue Canadienne de Sante Publique, 96(Journal Article), S45-S61.

Alfred, T. (2009). Peace, Power, Righteousness: An Indigenous Manifesto. Don Mills, Ontario: Oxford University Press.

Ball, J. (2004). Early Childhood care \& development programs as Hook and Hub: Promising Practices in First Nations Communities. University of Victoria, School of Child and Youth Care, Early Childhood Development Intercultural Programs. Retrieved from http://www.ecdip.org/docs/pdf/ECDIP\%20report\%20comp.pdf. 


\section{Early learning for Aboriginal children}

Ball, J., \& Elliot, E. (2005). Measuring Social Support in Aboriginal Early Childhood Programs. In J. Whitehead (Ed.), Research Connections Canada: Supporting Children and Families, Vol. 12, pp. 41-58. Ottawa: Canadian Child Care Federation.

Barman, J., Hebert, Y., \& McCaskill, D. (1986). The Legacy of the Past: An Overview. In J. Y. H. a. D. M. Barman (Ed.), Indian Education in Canada, Volume 1: The Legacy. Vancouver, British Columbia: UBC Press.

Barton, S. S., Thommasen, H. V., Tallio, B., Zhang, W., \& Michalos, A. C. (2005). Health and Quality of Life of Aboriginal Residential School Survivors, Bella Coola Valley, 2001. Social Indicators Research, 73(2), 295.

Battiste, M. (1986). Mi'kmaq Linguistic Integrity: A Case Study of Mi'kmawey School. In J. H. Barman, Y.; McCaskill, D. (Ed.), Indian Education in Canada, Volume 2: The Challenge (pp. 107-125). Vancouver, British Columbia: UBC Press.

Battiste, M. (2000). Reclaiming Indigenous Voice and Vision. Vancouver, British Columbia: UBC Press.

Bennett, M., Blackstock, C., \& De La Ronde, R. (2005). A Literature Review and Annotated Bibliography on Aspects of Aboriginal Child Welfare in Canada (2nd edition). Retrieved from http://www.fncaringsociety.com/sites/default/ files/docs/AboriginalCWLitReview_2ndEd.pdf.

Benoit, C., Carroll, D., \& Chaudhry, M. (2003). In search of a healing place: aboriginal women in Vancouver's downtown eastside. Social Science \& Medicine, 56(4), 821(813)-834.

Borrows, J. (1994). Constitutional Law From a First Nation Perspective: Self-government and the Royal Proclamation. University British Columbia Law Review, 28, 1-47.

Bramley, D., Hebert, P., Jackson, R., \& Chassin, M. (2004). Indigenous disparities in disease-specific mortality, a crosscountry comparison: New Zealand, Australia, Canada, and the United States. The New Zealand Medical Journal, 117(1207), 1207-1215.

Bramley, D., Hebert, P., Tuzzio, L., \& Chassin, M. (2005). Disparities in Indigenous Health: A Cross-Country Comparison Between New Zealand and the United States. American Journal of Public Health, 95(5), 844.

Brown, C. M., \& Smirles, K. E. (2003). Examining the Bicultural Ethnic Identity of American Indian Adolescents. American Indian Culture \& Research Journal, 29(3), Report: ED480493. 480427p. Retrieved from http://aisc. metapress.com/content/f64h8568h0hr6154/.

Cheshire, T. C. (2001). Cultural Transmission in Urban American Indian Families. American Behavioral Scientist, 44(9), 1528.

Corenblum, B. (1996). Development of identity in Native Indian children: review and possible futures. Canadian Journal of Native Studies, 16(1), 81-103.

Cox, S. (2002). Early Childhood Development - models and studies. Education Renewal Initiative Secretariat.

Dawson, J. (1988). "If My Children Are Proud": Native Education and the Problem of Self-Esteem. Canadian Journal of Native Education, 15(1), 43-50.

Frideres, J. S., \& Gadacz, R. (2001). Aboriginal Peoples in Canada: Contemporary Conflicts, 6th Edition. Toronto, Ontario: Pearson Education Canada Inc.

Friedel, T. L. (1999). The Role of Aboriginal Parents in Public Education: Barriers to Change in an Urban Setting. Canadian Journal of Native Education, 23(2), 139-158.

Greenwood, M. (2001). An Overview of the Development of Aboriginal Early Childhood Services in Canada. ERIC Document Reproduction Service No. ED 456954.

Greenwood, M., \& Shawana, P. (2000). Whispered Gently through Time. First Nations Quality Child Care: A National Study (Vol. ED 462-224). Ottawa, Ontario, Canada: HRDC. 


\section{First Peoples Child \& Family Review, Volume 7, Number 1, 2012}

Hanselmann, C. (2001). Urban Aboriginal People in Western Canada: Realities and Policies. Canada West Foundation. Retrieved from http://cwf.ca/pdf-docs/publications/September2001-Urban-Aboriginal-People-in-WesternCanada-Realities-and-Policies.pdf.

Health Canada. (1998). Taking Action on Population Health. A Position Paper for Health Promotion and Programs Branch Staff. Ottawa: Population Health Development Division, Health Promotion and Programs Branch.

Health Canada. (2000). Children Making A Community Whole: A Review of Aboriginal Head Start in Urban and Northern Communities. Ottawa, Ontario: Childhood and Youth Division, Health Canada.

HighScope Curriculum. (2012). Preschool Curriculum Retrieved 11/01/12, 2012

Lalonde, M. (1974). A new perspective on the health of Canadians. Ottawa: Minister of Supply and Services Canada. Retrieved from http://www.phac-aspc.gc.ca/ph-sp/pdf/perspect-eng.pdf.

Leitch, K. (2008). Reaching for the Top: A Report by the Advisor on Healthy Children and Youth. Ottawa, Ontario: Public Health Agency of Canada.

Lertzman, D. A. (2002). Rediscovering rites of passage: Education, transformatin, and the transition to sustainability. Ecology and Society, 5(2), 30.

Longboat, D. (1986). First Nations Control of Education. In J. H. Barman, Y.; McCaskill, D. (Ed.), Indian Education in Canada, Volume 2: The Challenge. Vancouver, British Columbia: UBC Press.

Mackay, R., \& Myles, L. (1995). A Major challenge for the Education System: Aboriginal Retention and Dropout. In M. B. Battiste, J. (Ed.), First Nations Education in Canada: The Circle Unfolds (pp. 157-178). Vancouver, British Columbia: UBC Press.

May, S., \& Aikman, S. (2003). Indigenous Education: addressing current issues and developments. Comparative Education, 39(2), 139.

Mendelson, M. (2006). Aboriginal Peoples and Postsecondary Education in Canada. Ottawa, ON: Caledon Institute of Social Policy.

Miller, J. (1991). Skyscrapers Hide the Heavens: A History of Indian-White Relations in Canada (Revised Ed.) (Vol. Revised). Toronto, Ontario: University of Toronto Press.

Mishibinijima, J. (2004). Uneasy Balance: Aboriginal Identity in Leadership Development. (Masters), Kingston, Ontario.

National Indian Brotherhood. (1972). Indian Control of Indian Education. In N. I. Brotherhood (Ed.). Ottawa, Ontario.

Newbold, K. B. (1998). Problems in Search of Solutions: Health and Canadian Aboriginals. Journal of Community Health, 23(1), 59-74.

Palmantier, M. (2005, 2005). Building a Community of Communities. Paper presented at the Results \& Discussion of the National Roundtable on Aboriginal ECD: What Can Research Offer Aboriginal Head Start.

Physicians for a Smoke-Free Canada. (2008). Health Effects of Chemicals Found in Cigarette Smoke. Retrieved 01/03/08, 2008, from http://www.smoke-free.ca/health/healththeeffectssmoke.htm.

Posluns, M. (2007). Some First Nations Policy Developments in Canada: Several Recent Developments Beyond the Grasp of Government. Indigenous Policy, 18(1).

Public Health Agency of Canada. (2000). Children Making a Community Whole: A Review of Aboriginal Head Start in Urban and Northern Communities. Retrieved from PHAC Publications website: http://publications.gc.ca/ collections/Collection/H39-532-2000E.pdf.

Smith, L. T. (1999). Decolonizing Methodologies: Research and Indigenous Peoples. Dunedin, New Zealand: University of Otago Press.

(c) Angela Mashford-Pringle 


\section{Early learning for Aboriginal children}

Stonechild, B. (2006). The New Buffalo: The Struggle for Aboriginal Post-Secondary Education in Canada. Winnipeg, Manitoba: University of Manitoba Press.

Tjepkema, M. (2002). The Health of the Off-reserve Aboriginal Population. Ottawa, Ontario.

Turner, D. (2006). This is Not a Peace Pipe: Towards a Critical Indigenous Philosophy. Toronto, Ontario, Canada: University of Toronto Press Inc.

Weaver, S. M. (1981). Making Canadian Indian policy: The hidden agenda, 1968-1970. Toronto: University of Toronto Press.

Wotherspoon, T. (2004). The Sociology of Education in Canada: Critical Perspectives (2nd Edition). Toronto, Ontario: Oxford Press.w 